\title{
Patterns of Facial Fractures Associated with Socio-demographic and Causative Factors: A Multi-Center Analysis from Karachi
}

\author{
Beenish Fatima Alam ${ }^{1}$ \\ Sidra Mohiuddin ${ }^{2}$ \\ Salim Hosein ${ }^{3}$ \\ Mervyn Hosein ${ }^{4}$
}

\author{
BDS, MSc, MFDS RCSED \\ BDS, MDS \\ MD \\ FDS RCS, FDS RCSE, FFD RCSI
}

OBJECTIVE: To assess the association of age, gender, and mechanism of injuries in patients presenting at tertiary care facilities of Karachi, Pakistan.

METHODOLOGY: A retrospective analysis of 1038 patients visiting private and public tertiary care dental hospital was conducted. Data was collected by means of a comprehensive history, clinical examination and radiological investigation. Qualitative variables were calculated as frequencies and percentage whereas means and standard deviation of quantitative variables were analyzed. Association among dependent and independent variables were assessed by Chi square test. RESULTS: A total of 1038 patients reported, which included $85 \%$ males and $15 \%$ females. Road traffic accidents accounted for $43 \%$ of injuries in males and $12 \%$ in females and were followed by falls in $15 \%$ males and $8 \%$ females. Body of mandible was the most frequently affected bone accounting for $32 \%$, while condyle was next commonly involved. Left side of mandible was noted to be more frequently affected. Only $6 \%$ of fractures involved the zygomatic region.

CONCLUSION: In this study RTA's were the most common cause of injuries among males and females in the second and third decades of life while in young children falls predominated. The mandibular body was the most frequently involved site followed by the condyle.

KEY WORDS: Maxillofacial injuries, Road traffic accidents, falls, body of mandible, trauma

HOW TO CITE: Alam BF, Mohiuddin S, Hosein S, Hosein M. Patterns of Facial Fractures Associated with Socio-demographic and Causative Factors: A Multi-Center Analysis from Karachi. J Pak Dent Assoc 2019;28(3):103-107.

DOI: https://doi.org/10.25301/JPDA.283.103

Received: 29 March 2019, Accepted: 17 June 2019

\section{INTRODUCTION}

$\mathrm{T}$ rauma to the maxillofacial region can cause injuries affecting the craniofacial skin, bones and neurovascular-sensory organs. These occur as consequences of falls, interpersonal violence, accidents or other associated etiological factors. ${ }^{1}$ The mandible is most commonly affected because of its prominent position on the face. ${ }^{2}$ Studies have concluded that within the mandible, $36 \%$ of fractures involve the condyle and $21 \%$ affect the mandibular body. The angle is involved in $20 \%$ of cases while parasymphyseal fractures account for $14 \%$ and the symphysis, coronoid, ramus and alveolar areas all account for up to 3\% each. Within the maxillary bone, Le Fort II fractures were

1. Assistant Professor \& HoD, Department of Oral Biology, Bahria Universtiy Medical and Dental College.

2. Assistant Professor \& HoD, Department of Community \& Preventive Dentistry, Ziauddin College of Dentistry, Karachi.

3. General Surgeon, Department of M.I.S, General Surgery, University of Nebraska Medical Center, USA.

4. Dean, Ziauddin College of Dentistry, Ziauddin University Karachi.

Corresponding author: "Dr. Mervyn Hosein” < mmh5617@gmail.com > the commonest followed by Le Fort I and Le Fort III. ${ }^{3}$

The factors associated with maxillofacial traumatic injuries vary considerably from one geographical region to the other. Statistics from developed countries show that physical assault is the most common cause of trauma whereas among developing countries road traffic accidents (RTA) are the leading factor., ${ }^{4,6}$ The WHO has documented that nearly one-third of traumatic injuries reported in developing countries are due to road traffic accidents (RTA) which significantly contribute towards increased mortality rates. ${ }^{7,8}$

The purpose of the current study was to assess the association of age, gender, and mechanism of injuries in patients presenting at tertiary care facilities of Karachi, Pakistan. Locally reported data have shown that males are more prone to facial injuries during their 2 nd and 3 rd decades of life with the most common etiologic factor being road traffic accidents (RTA) ${ }^{6,9}$ Moreover, studies conducted in past focused more upon the relation between different etiological factors and gender; therefore the association between facial injuries with gender, age and mode of injury 
needs to be addressed. Hence the objective of the current study is to assess the association of age and gender with mode of injury, as well as to analyze the site of injury with respect to age.

\section{METHODOLOGY}

This analytical cross sectional study was carried out in tertiary trauma care centers, based on primary data collected by a single examiner over a period of five years. A total of $(n=1038)$ cases were recorded; data collection was based on detailed history, thorough clinical examination as well as radiographic evaluation. Radiographs commonly used were: Orthopantomogram (OPG), Postero-anterior (PA) view of face, lateral view and lateral oblique view for mandibular injuries, with Occipito- Mental (OM /PNS) view used for mid face injuries. Computed Tomography (CT scans) tended to be used for complex and pan facial fractures usually associated with head injuries.

For evaluating dento-alveolar injuries intra oral radiographs were additionally used including periapical and occlusal views, as necessary.

Data was collated regarding age, gender, mode of injury, anatomical location of fracture in mandibular and maxillary bones based on R. Dingman and P. Natvig's classification10 as well as side of face affected: right, left or bilateral involvement.

Data analysis was performed using SPSS version 21 (Statistical Package of Social Sciences). Qualitative variables were calculated as frequencies and percentage whereas means and standard deviation of quantitative variables were analyzed. Association among dependent and independent variables were assessed by chi square test. Level of significance was kept $\mathrm{p}<0.05$.

\section{RESULTS}

A total of $n=1038$ patients were reported, out of which $85.5 \%(n=887)$ were males and $14.5 \%(n=151)$ were females. Ages ranged from 02 years to 80 years, with the mean age of $24.65 \pm 13.76$ years. In eighteen percent $(n=189)$ of cases, the ages ranged from of 0-10 years; the peak incidence was in patients with age range of 11 to 30 years that accounted for fifty seven percent $(n=593)$ of cases. However, twenty one percent $(n=216)$ of cases were from age range of 31-50 years, three percent $(n=33)$ from 51 to 70 years and less than one percent $(\mathrm{n}=07)$ were of 71 and above.

From the reported etiology of injury fifty six percent $(\mathrm{n}=582)$ were road traffic accidents, twenty two percent $(n=224)$ claimed to have accidental falls, twelve percent $(n=122)$ were victims of assault, four percent of cases $(n=38)$ presented with sports related injuries and three percent $(n=34)$ had industrial traumatic injuries while four percent $(n=38)$ of cases presented with other mode of injury.

Regarding the location of fracture in mandible; the mandibular body was most frequently involved at $32 \%$ $(n=327)$ followed by condylar process of mandible at $29 \%$ $(n=299)$. The chin region and angle of the mandible were reported to be $18.4 \%(\mathrm{n}=191)$ and $17 \%(\mathrm{n}=178)$ respectively while the least involved parts were alveolus $2.6 \%(n=27)$ and Pterygoid body $0.1 \%(01)$. The left side of the mandible was found to be most frequently involved at thirty eight percent $(n=395)$ while thirty six percent $(n=368)$ and twenty three percent $(n=239)$ of the cases reported with right side and bilateral involvement, respectively.

Only seventeen percent $(\mathrm{n}=174)$ maxillary fractures were

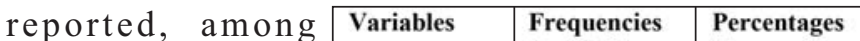
which the most common site was the Zygomatic/orbit region $5.8 \%(\mathrm{n}=60)$ followed by the maxilla body at five percent $(n=52)$. In maxillary fractures 9.5\% $(\mathrm{n}=99)$ patients were reported with bilateral involvement, $5.6 \% \quad(\mathrm{n}=58)$ and $5.1 \%(n=53)$ with right and left side, respectively. (Table 1)

Statistically significant difference was found between gender and cause of injury ( $\mathrm{p} \leq 0.003)$, with males injured more through road traffic accidents $(n=513)$ followed by accidental falls $(n=174)$. Whereas, females also encountered RTA more frequently. (Table 2)

Statistically significant difference was found among gender and location of the fracture in

\begin{tabular}{|c|c|c|}
\hline Variables & $\begin{array}{l}\text { Frequencies } \\
(n=1038)\end{array}$ & $\begin{array}{l}\text { Percentages } \\
\%\end{array}$ \\
\hline \multicolumn{3}{|c|}{ Gender } \\
\hline Male & 887 & 85.5 \\
\hline Female & 151 & 14.5 \\
\hline \multicolumn{3}{|c|}{ Age groups } \\
\hline $0-10$ years & 189 & 18.2 \\
\hline $11-30$ years & 593 & 57.1 \\
\hline $31-50$ years & 216 & 20.8 \\
\hline $51-70$ years & 33 & 3.2 \\
\hline 71- onwards & 07 & 0.7 \\
\hline \multicolumn{3}{|c|}{ Mode of injury } \\
\hline Assault & 122 & 11.8 \\
\hline Industrial & 34 & 3.3 \\
\hline Fall & 224 & 21.6 \\
\hline RTA & 582 & 56.1 \\
\hline Sports & 38 & 3.7 \\
\hline Others & 38 & 3.7 \\
\hline \multicolumn{3}{|c|}{ Location of fracture in Mandible } \\
\hline Angle & 178 & 17.1 \\
\hline Chin & 191 & 18.4 \\
\hline Body & 327 & 31.5 \\
\hline Coronoid & 02 & 0.2 \\
\hline $\begin{array}{l}\text { Pterygoid } \\
\text { body }\end{array}$ & 01 & 0.1 \\
\hline Alveolus & 27 & 2.6 \\
\hline Condyle & 299 & 28.8 \\
\hline others & 13 & 1.3 \\
\hline \multicolumn{3}{|c|}{ Sites in Mandible } \\
\hline Bilateral & 239 & 23 \\
\hline Right & 368 & 35.5 \\
\hline Left & 395 & 38.1 \\
\hline Others & 36 & 3.5 \\
\hline \multicolumn{3}{|c|}{ Location of fracture in Maxillae } \\
\hline Zygoma/orbit & 60 & 5.8 \\
\hline Orbit only & 13 & 1.3 \\
\hline Palate & 02 & 0.2 \\
\hline Alveolus & 14 & 1.3 \\
\hline Frontal & 15 & 1.4 \\
\hline Nasal & 18 & 1.7 \\
\hline Maxilla & 52 & 05 \\
\hline Others & 864 & 83.2 \\
\hline \multicolumn{3}{|c|}{ Sites in Maxillae } \\
\hline Bilateral & 99 & 9.5 \\
\hline Right & 58 & 5.6 \\
\hline Left & 53 & 5.1 \\
\hline others & 828 & 79.8 \\
\hline
\end{tabular}

Table 1: Descriptive analysis of the demographic variables, etiology and location of Mandibular \& Maxillary fractures along their sites 
Table 2: Association of gender and mode of injury

\begin{tabular}{|l|llllll|l|l|}
\hline Variable & \multicolumn{9}{|c|}{$\begin{array}{c}\text { Mode of injury } \\
\%(n)\end{array}$} & $\begin{array}{l}\text { Chi } \\
\text { square } \\
\text { value }\end{array}$ & P-value \\
\hline $\begin{array}{l}\text { Gender } \\
\text { Male }\end{array}$ & $\begin{array}{c}\text { Assault } \\
8.7(104)\end{array}$ & $\begin{array}{l}\text { Industrial } \\
2.7(32)\end{array}$ & $\begin{array}{l}\text { Fall } \\
14.6(174)\end{array}$ & $\begin{array}{l}\text { RTA } \\
43.1(513)\end{array}$ & $\begin{array}{l}\text { Sports } \\
2.9(34)\end{array}$ & $\begin{array}{l}\text { Others } \\
2.5(30)\end{array}$ & & \\
Female & $3(36)$ & $0.3(04)$ & $8.4(100)$ & $11.6(138)$ & $0.7(42)$ & $1.3(46)$ & 23.56 & 0.000 \\
\hline
\end{tabular}

Chi square test, ${ }^{*}$ statistically significant

Table 3: Association of gender and mandibular fractures

\begin{tabular}{|c|c|c|c|c|c|c|c|c|c|c|}
\hline \multirow{2}{*}{$\begin{array}{l}\text { Variable } \\
\text { Gender }\end{array}$} & \multicolumn{8}{|c|}{$\begin{array}{l}\text { Location of fracture in mandibular bone } \\
\qquad \%(\mathrm{n})\end{array}$} & \multirow{2}{*}{\begin{tabular}{|l} 
Chi \\
square \\
value \\
\end{tabular}} & \multirow[t]{2}{*}{\begin{tabular}{|l|}
$P-$ \\
value
\end{tabular}} \\
\hline & Angle & Chin & Body & Coronoid & $\begin{array}{l}\text { Posterior } \\
\text { body }\end{array}$ & Alveolus & Condyle & others & & \\
\hline Male & $12.8(152)$ & $14.2(169)$ & $23.5(280)$ & $0.1(1)$ & $0(0)^{\circ}$ & $1.5(18)$ & $21.4(255)$ & 1(11) & 23.56 & $0.001^{*}$ \\
\hline Female & $4.4(52)$ & $3.7(44)$ & $7.9(94)$ & $0.2(2)$ & $0.2(2)$ & $1.5(18)$ & $7.4(88)$ & $0.2(2)$ & & \\
\hline
\end{tabular}

Chi square test, ${ }^{*}$ statistically significant

Table 4: Association of age and mode of injury

\begin{tabular}{|l|lllllll|l|l|}
\hline Variable & \multicolumn{5}{c|}{$\begin{array}{c}\text { Mode of injury } \\
\%(n)\end{array}$} & $\begin{array}{l}\text { Chi } \\
\text { square } \\
\text { value }\end{array}$ & P-value \\
\hline Age & Assault & Industrial & Fall & RTA & Sports & Others & \\
0-10 years & $2.1(04)$ & $0.5(01)$ & $56.6(107)$ & $34.9(66)$ & $3.2(06)$ & $2.6(05)$ & \\
11-30 years & $12.8(76)$ & $03(18)$ & $15.5(92)$ & $61.6(365)$ & $4.4(26)$ & $2.7(16)$ & 2.09 & 0.000 \\
31-50 years & $16.2(35)$ & $06(13)$ & $9.3(20)$ & $59.7(129)$ & $1.9(04)$ & $6.9(15)$ & \\
51-70 years & $18.2(06)$ & $6.1(02)$ & $12.1(04)$ & $57.6(19)$ & $0(0)$ & $6.1(02)$ & \\
$\begin{array}{l}71 \quad \text { and } \\
\text { onwards }\end{array}$ & $14.3(01)$ & $0(0)$ & $14.3(01)$ & $42.9(03)$ & $28.6(02)$ & $0(0)$ & & \\
\hline
\end{tabular}

Chi square test, ${ }^{*}$ statistically significant

mandibular bone ( $\mathrm{p} \leq 0.000)$, among males, mandibular body $(n=280)$ followed by condylar process $(n=255)$ were the most frequent reported sites. (Table 3)

Statistically significant difference was noted among the age ranges of the study subjects and the cause of the injury $(p \leq 0.000)$. In the age range of 11 to 30 years road traffic accidents $(n=365)$ were more frequently reported. However, histories of accidental fall $(n=107)$ were more common in the age range of ten years and below. (Table 4)

\section{DISCUSSION}

The majority of the samples in the current study were adult males, in the second and third decade of life and this was statistically significant. Road traffic accidents are a major cause of injury followed by accidental falls. The latter mode of injury was found to be more common amongst children in the first decade of life. Being most prone to injury the body of mandible was the most commonly affected site, followed by the condyle itself. Zygomatic region was noted to be more likely to be injured followed by trauma to maxillary bone among fractures associated with the mid face.

In the current study, the majority of injuries involved the males; these findings concur with previous studies. ${ }^{11,12,13}$
The overall male to female ratio was 4:1 which was similar to the findings of other studies. ${ }^{14,15}$ Furthermore, males in the second and third decades of life were most commonly involved; these findings also were similar to other regionally reported local studies. ${ }^{16,17,18}$ This may be because men are more freely mobile and involved in outdoor activities as compared to women, particularly in our socio-economic setting, often relying on unsafe modes of transport such as motorcycles, hanging on to buses or jaywalking. Furthermore, in the current study, young children in the one to ten years age group were more prone to injuries caused by accidental falls, and these findings are consistent with other studies. ${ }^{19,20,21}$ Children of that reported age group are growing up fast and are more liable to injuries while playing; occasionally they fall from beds or slip from parents hands due to inadequate safety measures and carelessness.

In the current study road traffic accidents were found to be a major cause of injury, approximately half of the sample however differs from other studies. ${ }^{22,23}$ Moreover, statistics from western world have demonstrated physical assault as an important cause of maxillofacial injury. ${ }^{24}$ RTA's are more common due to failure to follow safety measures while driving; such as the use of seat belts or wearing of helmets and weaving through traffic by bikers, and also due to poor maintenance of roads. In industrialized countries these basic rules of the road are strictly applied and followed. Injuries due to accidental falls were the next most common cause of injury; this is consistent with the study conducted in India and with previously reported studies. ${ }^{25,26}$ While child abuse must always be considered in cases of trauma especially those that do not fit described histories and patterns, or when issues of possible negligence of parents and caretakers is involved, the active nature of growing children does tend to make them more accident prone. ${ }^{27}$

The most common mandibular site of fracture observed in the current study was of the body of mandible followed by the condylar part. Similar finding were reported by previously conducted studies. ${ }^{28,29}$ Apart from road traffic accidents being more common in our part of the world, high mobility and relative lack of surrounding bony support of the mandibular bone as compared to other facial bones is a contributing factor. However these finding were divergent from the statistics reported from developed countries. ${ }^{30,31,32}$ In the west, assault was a major risk factor which has been attributed to stressful everyday routines and interpersonal differences along with higher usage of drugs and alcohol in those societies. Strict laws regarding drinking and driving and casual alcohol breath testing by police make RTA's on this account relatively less common.

In the current study, statistically significant association 
has been found between gender and mode of injury. Males predominate, due to their aggressive nature as well as more involvement in outdoor activities and freedom of movement, as compared to females in our eastern society. Current study demonstrated RTA as major cause of trauma among males, which can be attributed to improper implementation of traffic rules and regulations, among other reasons. Females reportedly suffered more from falls, some of which could be due to domestic violence which is reportedly more common yet unrecognized within developing countries. ${ }^{33}$ Location of fracture within the mandible also demonstrates considerable relation with gender. It is seen that body of mandible is the most commonly involved site followed by condyle, due to road traffic accidents and falls, commonly affecting males belonging to second and third decades of life.

Among the maxillary fractures noted in the current study, zygomatic region was the commonest site to be involved and affected by trauma; similar findings were stated by previous studies. ${ }^{34}$ The subsequent frequently affected sites were the maxillary bone region which coincides with study conducted by previous researchers. ${ }^{35,36,37}$ Zygomatic bone is a prominent bone of the face and during interpersonal assault is frequently subjected to trauma. The basic protective tendency in the midface area is to turn the face downwards and to the side in order to protect the thinner central naso-orbital structures. ${ }^{38}$

\section{CONCLUSION}

RTA's are the most common cause of injuries in males and females between the second to third decade with the body of mandible being most frequently involved followed by the condyle. Falls among young children was the primary cause of injury followed by RTA.

\section{RECOMMENDATIONS}

It is strongly recommended that road infrastructure needs urgent maintenance to reduce the tendency of sudden braking and evasive driving. Equally, the driving rules and regulations, especially those related to the age of drivers, speed control and the wearing of seat belts and helmets needs to be strongly followed and strict actions needs to be taken against violators. Thirdly, public awareness programs regarding safely measures and precautions needed while driving; and relating to issues of child safety and negligence / abuse precautions must be widely publicized via the media.

\section{CONFLICT OF INTEREST}

None declared

\section{REFERENCES}

1. Ström C, Nordenram A, Fischer K. Jaw fractures in the County of Kopparberg and Stockholm 1979-1988. A retrospective comparative study of frequency and cause with special reference to assault. Swedish Dent J. 1991;15:285-89.

2. Chrcanovic BR, Freire-Maia B, Souza LN, Araújo VO, Abreu MH. Facial fractures: a 1- year retrospective study in a hospital in Belo Horizonte. Braz Oral Res 2004; 18: 322-28.

https://doi.org/10.1590/S1806-83242004000400009

3. Pohchi A, Abdul Razak NH, Rajion ZA, Alam MK. Maxillofacial fracture at Hospital Universiti Sains Malaysia (HUSM): a five year retrospective study. Int Med J. 2013 ;20:487-89.

4. Roccia F, Bianchi F, Zavattero E, Tanteri G, Ramieri G. Characteristics of maxillofacial trauma in females: a retrospective analysis of 367 patients. J Cranio-Maxillofaci Surg. 2010;38:314-19. https://doi.org/10.1016/j.jcms.2009.10.002

5. Da Nóbrega LM, de Macedo Bernardino Í, Leal PM, de Castro Martins C, Granville-Garcia AF, d'Avila S. Traffic accidents, maxillofacial injuries and risk factors: A systematic review of observational studies. J Evidence Based Med. 2019 ;12:3-8.

https://doi.org/10.1111/jebm.12332

6. Abbas I, Fayyaz M, Shah I, Khan MA, Qazi SH, Munir N, Bibi A, Abbasi M. Demographic distribution of maxillofacial fractures in Ayub Teaching Hospital: 7-year review. J Ayub med coll. 2009;21:110-12.

7. Aldwsari OM, Aldosari KH, Alzahrani MK, Alzahrani ZA, Alanazi $\mathrm{AH}$, Alkhathlan KM, et al. Associated head injuries and survival rate of patients with maxillofacial fractures in road traffic accident: A prospective study in Saudi Arabia. J family med primary care.2018;7:154854

https://doi.org/10.4103/jfmpc.jfmpc_101_18

8. Syed KB. Maxillofacial injuries due to road traffic accidents in Saudi Arabia: a review of incidence, demographic factors \& prevention strategies. Int J Med Dent Sci. 2017 ;6:1386-91.

https://doi.org/10.19056/ijmdsjssmes/2017/v6i1/125560

9. Hameed F, Gul W, Ali I, Hanif T. Pattern of Maxillofacial Injuries due to Motorcycle Related Road Traffic Accidents at A Tertiary Care Hospital in Karachi, Pakistan. Ann Jinnah Sindh Med Uni. 2017;3:80-5.

10. Cornelius CP, Audigé L, Kunz C, Rudderman R, Buitrago-Téllez $\mathrm{CH}$, Frodel J, et al. The comprehensive AOCMF classification system: mandible fractures-level 2 tutorial. Craniomaxillofac trauma reconstruct. 2014 7:S015-30.

https://doi.org/10.1055/s-0034-1389557

11. Miguens-Jr SA, Borges TS, Dietrich LA, Oliveira MC, Hernandez PA, Kramer PF. A retrospective study of oral and maxillofacial injuries in an emergency hospital in Southern Brazil. Pesquisa Brasileira em Odontopediatria e Clínica Integrada. 2016 ;16:339-50. https://doi.org/10.4034/PBOCI.2016.161.36

12. Elarabi MS, Bataineh AB. Changing pattern and etiology of maxillofacial fractures during the civil uprising in Western Libya. 
Medicina oral, patologia oral y cirugia bucal. 2018;23:e248. https://doi.org/10.4317/medoral.22268

13. Fama F, Cicciu M, Sindoni A, Nastro-Siniscalchi E, Falzea R, Cervino G, Polito F, De Ponte F, Gioffre-Florio M. Maxillofacial and concomitant serious injuries: An eight-year single center experience. Chinese J traumatol. 2017;20:4-8.

https://doi.org/10.1016/j.cjtee.2016.11.003

14. Marker P, Nielsen A, Bastian HL. Fractures of the mandibular condyle. Part 1: patterns of distribution of types and causes of fractures in 348 patients. Br J Oral Maxillofac Surg 2000; 38:417-21. https://doi.org/10.1054/bjom.2000.0317

15. Bali R, Sharma P, Garg A, Dhillon G. A comprehensive study on maxillofacial trauma conducted in Yamunanagar, India. J injury violence res. $2013 ; 5: 108-116$

https://doi.org/10.5249/jivr.v5i2.331

16. Ahmed S, Punjabi SK, Ur-Rehman H, Aslam MA, Haider SM. Analysis of maxillofacial injuries spread over one year period in Karachi sample. Pak Oral Dent J. 2014;34 197-200

17. Khan A, Salam A, Khitab U, Khan MT. Pattern of mandibular fractures - a study. Pak Oral Dent J 2009; 29: 221-24.

18. Mulk NU, Tareen M, Hamad J, Rehman HU, Khan C. Frequency of maxillofacial skeletal injuries according to age site and cause. Pak Orthod J. 2018;10:116-19.

19. Vyas RM, Dickinson BP, Wasson KL, Roostaeian J, Bradley JP. Pediatric facial fractures: current national incidence, distribution, and health care resource use. J Craniofacial Surg. 2008;19:339-49. https://doi.org/10.1097/SCS.0b013e31814fb5e3

20. Zimmermann CE, Troulis MJ, Kaban LB. Pediatric facial fractures: recent advances in prevention, diagnosis and management. Inte J Oral and maxillofac surg. 2005;34:823-33.

https://doi.org/10.1016/j.ijom.2005.06.015

21. Ferreira PC, Amarante JM, Silva PN, Rodrigues JM, Choupina MP, Silva ÁC et al. Retrospective study of 1251 maxillofacial fractures in children and adolescents. Plastic reconst surg. $2005 ; 115: 1500-08$. https://doi.org/10.1097/01.PRS.0000160268.20294.FD

22. Hussain SS, Ahmad M, Khan MI, Anwar M, Amin M, Ajmal S, Tariq F, Ahmad N, Iqbal T, Malik SA. Maxillofacial trauma: current practice in management at Pakistan Institute of Medical Sciences. J Ayub Med Colle. 2003;15:8-11

23. Qiam D. Analysis of 362 cases of maxillofacial injuries in northern region of Pakistan. Pak Oral Dent J. 1991;11:35-43.

24. Hasnat A, Hoque AE, Azam MS, Kamrujjaman M, Akhtar M. Pattern of maxillofacial trauma among patients with head injuries. Update Dent Coll J. $2017 ; 7: 14-20$.

https://doi.org/10.3329/updcj.v7i1.33304

25. Shah A, Shah AA, Salam A. Maxillofacial fractures: analysis of demographic distribution in 320 patients. Pak Oral Dent J 2006; 26: 235-37.
26. Kumar GA, Dhupar V, Akkara F, Kumar SP. Patterns of maxillofacial fractures in Goa. J Maxillofac Oral Surg. 2015 Jun 1;14:138-41. https://doi.org/10.1007/s12663-013-0583-7

27. Hoppe IC, Kordahi AM, Lee ES, Granick MS. Pediatric facial fractures: interpersonal violence as a mechanism of injury. J Craniofac Surg. 2015;26: 1446-49.

https://doi.org/10.1097/SCS.0000000000001822

28. Pandey S, Roychoudhury A, Bhutia O, Singhal M, Sagar S, Pandey RM. Study of the pattern of maxillofacial fractures seen at a tertiary care hospital in north India. J Maxillofac Oral Surg. 2015;14:32-39. https://doi.org/10.1007/s12663-013-0578-4

29. Oji C. Jaw fractures in Enugu, Nigeria, 1985-95. Brit J Oral Maxillofac Surg. 1999; 37:106-9.

https://doi.org/10.1054/bjom.1997.0083

30. Schön R, Roveda SI, Carter B. Mandibular fractures in Townsville, Australia: incidence, aetiology and treatment using the $2.0 \mathrm{AO} / \mathrm{ASIF}$ miniplate system. Brit J Oral Maxillofac Surg. 2001; 39:145-48. https://doi.org/10.1054/bjom.2000.0607

31. Adhikari RB, Karmacharya A, Malla N. Pattern of mandibular fractures in western region of Nepal. Nepal J Med Sci. 2012;1:45-8. https://doi.org/10.3126/njms.v1i1.5798

32. Chrcanovic BR, Abreu MH, Freire-Maia B, Souza LN. 1,454 mandibular fractures: a 3-year study in a hospital in Belo Horizonte, Brazil. J Cranio-Maxillofac Surg. 2012;40:116-23.

https://doi.org/10.1016/j.jcms.2011.03.012

33. Le BT, Dierks EJ, Ueeck BA, Homer LD, Potter BF. Maxillofacial injuries associated with domestic violence. J Oral Maxillofac Surg. 2001;59:1277-83.

https://doi.org/10.1053/joms.2001.27490

34. Klenk G, Kovacs. Etiology and Patterns of Facial Fractures in the United Arab Emirates. J Craniofac Surg. 2003;14: 78-84. https://doi.org/10.1097/00001665-200301000-00014

35. Manodh P, Shankar DP, Pradeep D, Santhosh R, Murugan A. Incidence and patterns of maxillofacial trauma-a retrospective analysis of 3611 patients-an update. Oral Maxillofac Surg. 2016;20:377-83. https://doi.org/10.1007/s10006-016-0576-z

36. Eggensperger N, Smolka K, Scheidegger B, Zimmermann H, IIZuka T. A 3-year survey of assault-related maxillofacial fractures in central Switzerland. J Cranio-Maxillofac Surg. 2007;35:161-67. https://doi.org/10.1016/j.jcms.2007.01.002

37. Krishnan UC, Byanyima RK, Faith A, Kamulegeya A. Maxillofacial injuries among trauma patients undergoing head computerized tomography; A Ugandan experience. International journal of critical illness and injury science. 2017;7:236-40

https://doi.org/10.4103/2229-5151.219950

38. Tripathi GM, Sharma D, Gaharwar AP, Gupta R, Shukla D, Shukla V. Analysis of Prevalence and Pattern of Zygomatic Complex Fractures in North-Eastern Part of Madhya Pradesh, India. Int J Contemp Med Res 2016;3:1878-81. 